\title{
A Rare Pattern of Brachial Artery Variation - Case Report
}

\author{
Un Patrón de Variación Raro de la Arteria Braquial - Reporte de Caso
}

Jacomo, A. L."; Martinez, C. A. R. ${ }^{* *}$ Saleh, S. O."; Andrade, M.* \& Akamatsu, F. E.*

JACOMO, A. L.; MARTINEZ, C. A. R.; SALEH, S. O.; ANDRADE, M. \& AKAMATSU, F. E. A rare pattern of brachial artery variation - case report. Int. J. Morphol., 32(2):542-545, 2014.

SUMMARY: Unlike the venous system, variations in arterial anatomy are less frequent and most of them affect visceral arteries. In limbs, variations of the brachial artery are the most reported and at least six different patterns have been described so far. The commonest is the superficial brachial artery which lies superficially to the median nerve. Much less prevalent are the high origin of the radial artery (brachioradial artery) or the existence of a doubled brachial artery (accessory brachial artery). We present a previously undescribed pattern of brachial artery variation. During dissection of the right upper limb of a 60 year-old male embalmed cadaver, we found the bifurcation of the brachial artery in the proximal portion of the middle third of the arm. Its medial branch reaches the medial aspect of the arm, posterior to the median nerve. Afterwards, this medial branch redirects laterally and crosses again the median nerve, this time lying anterior to the nerve until it reaches the lateral aspect of the arm. At the elbow level, the medial branch originates the radial artery. The lateral branch of the brachial artery remains lateral to the median nerve and continues as ulnar artery and originates the interosseus artery.

KEY WORDS: Artery; Brachial; Variation; Anatomy.

\section{INTRODUCTION}

The brachial artery is a continuation of the axillary artery, originating at distal edge of teres major muscle tendon and ending giving off the radial and ulnar arteries, inferior to the elbow joint, at the level of the radial head. Anatomical variations of this artery occur in almost $20 \%$ of the cases and are commonly found in routine dissections or clinical practice (Lippert, 1985; McCormack et al., 1953; RodriguezNiedenfuhr et al., 2001). The knowledge of these variations is important to interventional surgeons, radiologists and anatomists. The brachial artery may be absent in rare cases (Ciervo et al., 2001); divided in a higher level (Standring, 2005), trifurcating (Malci-Gürbuz et al., 2002; Vollala et al., 2008) and originating accessory branches that may or may not bifurcate into radial and ulnar arteries (McCormack et al.; Yang et al., 2008). In this case report, we described just one of these variations of the brachial artery, with a pattern never reported before in the literature, and relevant for clinical practice, surgeons and radiologists.

\section{CASE REPORT}

During routine dissection in the Anatomy Laboratory of the Discipline of Human Structural Topography, at the Medical School, University of São Paulo, an unusual arterial variation was observed in a 60-year-old male cadaver preserved in formaldehyde solution. The dissection was initiated with skin incision of the anterior arm. This incision occurred longitudinal to the middle portion, thus the skin was pulled apart and subcutaneous cell tissue and brachial biceps muscle were lateralized in order to observe the brachial artery. So, it was possible to observe in the proximal portion of the middle third of the arm, an abnormal artery bifurcation; a dissection was then performed and extended for the anterior area of the forearm, following the same sequence of anatomical planes of arm dissection and findings were documented.

The brachial artery was found bifurcating in the proximal portion of the middle third of the arm, forming a lateral and another medial branch. The medial branch headed medially by passing posterior to the median nerve and in the distal third of the arm it turned towards the lateral, crossing the median nerve and headed, in the forearm, to form the radial artery. On the other hand, the lateral branch continued medially to the brachial biceps muscle and in the distal third of the arm crossed posterior to the medial branch and headed to the cubital fossa, forming the common interosseous artery and continued as ulnar artery (Fig. 1).

\footnotetext{
* Laboratory of Medical Research (LIM 02), Department of Surgery, University of São Paulo Medical School, São Paulo, Brazil.

** Universidade São Francisco, Bragança Paulista, São Paulo, Brazil.
} 

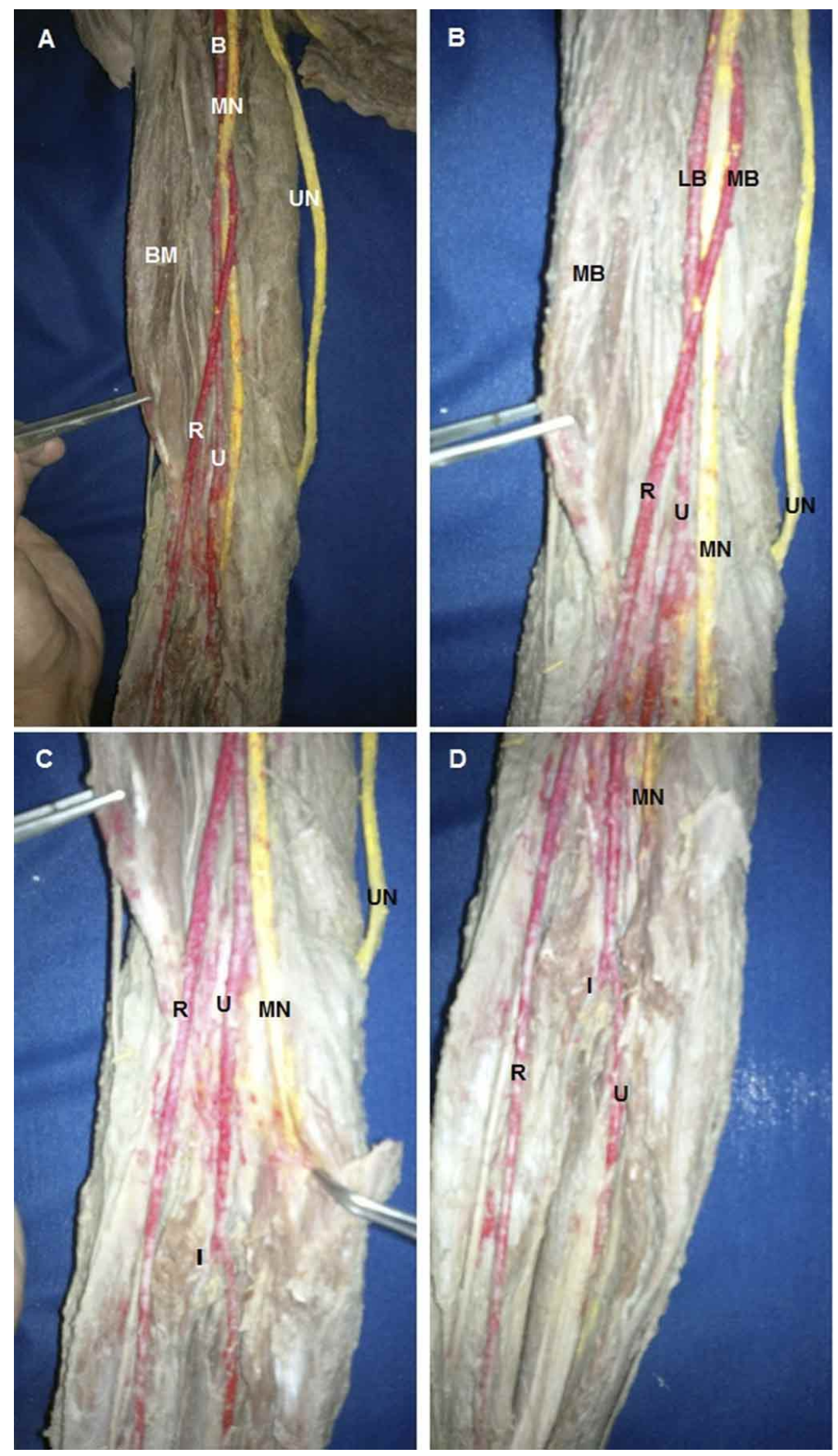

Fig. 1. Brachial Biceps Muscle (BM); lateral branch (LB); medial branch (MB), ulnar nerve (UN), median nerve $(\mathrm{MN})$, radial artery $(\mathrm{R})$; ulnar artery $(\mathrm{U})$, brachial artery (B); interosseous artery (I).

\section{DISCUSSION}

Variations in number and path of the upper limb arteries are important for and surgical practice (Cohen, 1948; Hazlett, 1949; Jurjus et al. 1986); it has attracted the attention of anatomists and many other medical specialties due to greater improvement of diagnostic and invasive or not therapeutic techniques, and the possibility of iatrogenic injury. Usually, these anatomical variations can be explained from an embryological point of view. 
Embryologically, the arteries of the upper limbs are originated from the primitive axial artery (deep system) and superficial brachial artery (Muller, 1903; Senior, 1926; Singer, 1933; Schwyzer \& De Garis, 1935; Rodriguez-Baeza A, et al., 1995). The brachial, axillary and interosseous arteries derive from primitive axial artery, transitorily the median artery arises as a branch of the interosseous artery, involuting towards the artery concomitant to the median nerve (Mrazková, 1973, 1989). Proximally, the superficial brachial artery unites to the brachial and axillary segments of the primitive axial artery by means of several trunks. The superficial brachial artery distally anastomoses with the brachial artery (branch of the primitive axial artery) via medial branch of the superficial brachial artery (superficial antebrachial artery) and another lateral branch of superficial brachial artery. The antebrachial artery originates two branches: one median (anastomosing with the deep trunk of the radial artery, the terminal branch of the primitive axial artery) and another one, the ulnar branch, which anastomoses with the trunk of the deep ulnar artery (terminal branch of the primitive axial artery); due to these anastomoses, there is an increase in local blood flow leading to involution of proximal segment of the superficial brachial artery, that is, the origin of the radial artery (Senior; Singer) and an ulnar artery would arise directly from the primitive axial artery. Changes in the origin or involution of these segments are the cause of morphogenetic alterations found in the anatomy of the arteries of the upper limbs. High bifurcation of the brachial artery is considered rare, found in only $0.5 \%$ in 202 cadavers dissected by Bertolazzo (1981). In a study involving 72 upper limbs Brazilian adult cadavers of both sexes, preserved in formaldehyde solution, the bifurcation of the brachial artery was analyzed using as reference the biepicondilar line (LBE) of elbow and its relationship with the median nerve (Olave et al., 1997) and in $87.5 \%$ of the cases, the brachial artery distally bifurcated from this line, $11.1 \%$ proximally and the level of it $1.4 \%$ of cases. When the bifurcation was distally to LBE, the median nerve crossed ventrally the brachial artery in $54.9 \%$ of cases and $23.5 \%$ dorsally; when the bifurcation was proximal to LBE, the median nerve crossed the brachial artery in two cases. Several authors have described in detail arterial variations of the upper limb, as Adachi (1928), Coleman \& Anson (1961) and McCormack et al., the latter with a sample with 750 cases, in which found $18.5 \%$ of anatomical variations, being $77 \%$ of the cases with high origin of radial artery, while the ulnar artery was responsible for $12.2 \%$ of the variations. Pelin et al. (2006) observed an incidence of $14.27 \%$ of high origin of the radial artery (axillary or brachial artery) in dissections of cadavers and $9.75 \%$ in an angiographic study. Docimo et al. (2009) described a case of arterial malformation in a 61-year old female cadaver dissection, whose origin of radial artery occurred in the axillary artery with superficial path in an anterior compartment of the arm converging deeply at the brachial artery in the cubital fossa.
Yang et al. dissected 304 upper limbs of Korean cadavers, and observed the presence of superficial brachial artery originating in the axillary artery and with superficial path to the median nerve in $12.2 \%$ of the limbs with unilateral predominance in 16 and bilateral in 10 cadavers. SBA produced ulnar and radial arteries in the cubital fossa $(8.9 \%)$, continued in the forearm as a radial artery $(2.3 \%)$ and ending in the arm in $1.0 \%$ of cases.

Occasionally, trifurcation of the brachial artery occurs. Malci-Gürbuz et al. described one case of trifurcation of brachial artery occurred $4.9 \mathrm{~cm}$ from the origin of the brachial artery, forming three terminal branches: radial, ulnar and superior collateral ulnar. Vollala et al. described another case in which the trifurcation of the brachial artery occurred in the proximal third of the forearm, creating the following arteries: radial, ulnar and common interosseous and these three arterial branches passed deep to the pronator teres muscle.

Regarding the anatomical variation described, we believe that the knowledge of this unusual shape is extremely important, especially because the influence it can exert on the conduct of clinical or surgical procedures, since this variation has not only present alteration in the origin of radial and ulnar arteries, but also on the path through the limb.

JACOMO, A. L.; MARTINEZ, C. A. R.; SALEH, S. O.; ANDRADE, M. \& AKAMATSU, F. E. Un patron de variación raro de la arteria braquial - reporte de caso. Int. J. Morphol., 32(2):542-545, 2014.

RESUMEN: A diferencia del sistema venoso, las variaciones en la anatomía arterial son menos frecuentes y la mayoría afecta a las arterias viscerales. En los miembros, las variaciones de la arteria braquial son las más informadas y por lo menos seis diferentes patrones han sido descritos. La variación más común es de la arteria braquial superficial que está superficialmente al nervio mediano. Mucho menos frecuente es el origen alto de la arteria braquial radial (la arteria braquiorradial) o la existencia de una arteria braquial doble (arteria braquial accesoria). Presentamos un patrón de variación no descrito de la arteria braquial observado durante la disección del miembro superior derecho de un cadáver en un hombre de 60 años de edad. Encontramos la bifurcación de la arteria braquial en la porción medial del brazo, pasando posterior al nervio mediano. Luego, esta rama medial se redirecciona lateralmente y cruza nuevamente al nervio mediano, esta vez, anterior a él, hasta alcanzar la región lateral del brazo. A nivel de la flexura del codo, la rama medial origina la arteria radial. La rama lateral de la arteria braquial se mantiene lateral al nervio mediano y continúa como arteria ulnar y origina la arteria interósea común.

PALABRAS CLAVE: Arteria; Braquial; Variación; Anatomía. 


\section{REFERENCES}

Adachi, B. Das Arteriensystem der Japaner. Kyoto, Maruzen, 1928. pp.234-7.

Bertolazzo, W.; Romero, A. M.; Bica, D. T.; Cavalheiro, F. C.; Barroso Filho, F.; Pezzi, L. H. \& Kauffman, L. Variação anatômica da artéria braquial bifurcação alta. Rev. Bras. Cir., 71(3):173-80, 1981.

Ciervo, A.; Kahn, M.; Pangilinan, A. J. \& Dardik, H. Absence of the braquial artery: Report of a rare human variation and review of upper extremity arterial anomalies. J. Vasc. Surg., 33(1):191-4, 2001.

Cohen, S. M. Accidental intra-arterial injection of drugs. Lancet, 2(6524):409-17, 1948.

Coleman, S. \& Anson, B. Arterial patterns in the hand based upon a study of 650 specimens. Surg. Gynecol. Obstet., 113(4):409-24, 1961.

Docimo, S.; Kornitsky, D. E.; Hill, R. V. \& Elkowitz, D. E. Arterio-arterial malformation between a high origin radial artery and brachial artery with the cubital fossa - its clinical and embryological significance: a case report. Cases J., 24(2):6836, 2009.

Hazlett, J. W. The superficial ulnar artery with reference to accidental intra-arterial injection. Can. Med. Assoc. J., 61(3):289-93, 1949.

Jurjus, A.; Sfeir, R. \& Bezirdjian, R. Unusual variation of the arterial pattern of the human upper limb. Anat. Rec., 215(1):82-3, 1986.

Lippert, H. \& Pabst, R. Arterial variations in man. Munich, Bergman, 1985. pp.66-77.

Malci-Gürbuz, J.; Gurunluoglu, R.; Ozdogmus, O. \& Yalin, A. Unique case of trifurcation of the brachial artery: Its clinical significance. Clin. Anat., 15(3):224-7, 2002.

McCormack, L. J.; Caulwell, E. W. \& Anson, B. J. Braquial and antebraquial arterial patterns. Surg. Gynecol. Obstet., 96(1):43-54, 1953.

Mrázková, O. Ontogenese of arterial trunks in the human forearm. Folia Morphol., 21(2):193-6, 1973.

Mrázková, O. Le réseau vasculaire du member supérieur et ses relations avec les muscles pendant l'ontogênèse humaine. Angéiologie, 41(2):41-52, 1989.

Muller, E. Beiträge zur Morphologie des Gefässystems. I. Die Armarterien des Menschen. Anat. Hefte, 22:377-575, 1903.
Olave, E.; Braga, M. T. T.; Gabrielli, C. \& Rodrigues, C. F. S. Nivel de bifurcacion de la arteria braquial y sus relaciones con el nervio mediano. Rev. Chil. Anat., 15(1):99-105, 1997.

Pelin, C.; Zagyapan, R.; Mas, N. \& Karabay, G. An unusual course of the radial artery. Folia Morphol. (Warsz), 65(4):410-3, 2006.

Rodríguez-Baeza, A.; Nebot, J.; Ferreira, B.; Reina, F.; Pérez, J. \& Sanudo, J. R. An anatomical study and ontogenetic explanation of 23 cases with variations in the main pattern of the human brachio-antebrachial arteries. J. Anat., 187(Pt. 2):473-9, 1995.

Rodriguez-Niedenfuhr, M.; Vasquez, T.; Nearn, L.; Ferreira B.; Parkin, I. \& Sanudo, J. R. Variations of the arterial pattern in the upper limb revised: a morphological and statistical study, with a review of the literature. J. Anat., 199(Pt. 5):547-66, 2001.

Senior, H. D. A note on the development of the radial artery. Anat. Rec., 32:220-1, 1926.

Singer, E. Embriological pattern persisting in the arteries of the arm. Anat. Rec., 55:403-9, 1933.

Standring, S. Gray's Anatomy. 39 $9^{\text {th }}$ ed. Edinburgh, Elsevier Churchill Livingstone, 2005.

Schwyzer, A. G. \& De Garis, C. H. F. Three diverse patterns of the arteria brachialis superficialis in man. Anat. Rec., 63:405-16, 1935.

Vollala, V. R.; Nagabhooshana, S. \& Bhat, S. M. Trifurcation of braquial artery with variant cause of radial artery: Rare observation. Anat. Sci. Int., 83(4):307-9, 2008.

Yang, H. J.; Gil, Y. C.; Jung, W. S. \& Lee, H. Y. Variations of the superficial branchial artery in Korean Cadavers. J. Korean Med. Sci., 23(5):884-7, 2008.

Correspondence to:

Flávia Emi Akamatsu

Rua Alexandre Dumas 1410, ap. 154.

Chácara Santo Antonio

Santo Amaro

CEP:04717003

São Paulo, SP

BRASIL

Email: flaea@usp.br

Received: 22-12-2012

Accepted: 14-01-2014 